\title{
Modifikasi Kacang Kedelai (Glycine Max) dan Hati Ayam Pada Sosis Ayam Sebagai Alternatif Sosis Tinggi Protein dan Zat Besi
}

\section{Soybean Modification (Glycine Max) and Chicken Liver towards Chicken Sausage as an Alternative of High Protein and High Iron Sausage}

\author{
Annisa Nurul Lutfiah ${ }^{1 *}$, Annis Catur $\mathrm{Adi}^{1}{ }^{1}$ Dominikus Raditya Atmaka ${ }^{1}$
}

\begin{abstract}
ABSTRAK
Latar Belakang: Hati ayam merupakan sumber zat besi yang baik dan kacang kedelai adalah jenis kacang-kacangan kaya protein dan besi yang dapat diolah menjadi sosis sebagai snack ataupun lauk tinggi protein dan zat besi.

Tujuan: Tujuan penelitian ini untuk menganalisis daya terima, kadar protein dan zat besi pada sosis dengan modifikasi hati ayam dan kacang kedelai.

Metode: Jenis penelitian ini yaitu experimental murni dengan rangangan acak lengkap (RAL). Terdapat 4 formula dengan 4 kali pengulangan, yaitu F2 ( $35 \mathrm{~g}$ hati ayam dan $65 \mathrm{~g}$ kacang kedelai), F3 (45 g hati ayam dan $55 \mathrm{~g}$ kacang kedelai), dan F4 (55 g hati ayam dan $45 \mathrm{~g}$ kacang kedelai). Terdapat 27 panelis pada penelitian ini yaitu tidak terlatih.

Hasil: Berdasarkan uji daya terima yang paling disukai panelis tidak terlatih yaitu formula F4 (55 g hati ayam dan $45 \mathrm{~g}$ kacang kedelai). Kandungan protein dan zat besi pada per $100 \mathrm{~g}$ sosis F4 yaitu 17,21 g dan 7,415 mg. Terdapat perbedaan yang signifikan antara F0 dengan F4 pada karakteristik aroma $(p=0,045)$, kekenyalan $(p<0,001)$ dan rasa $(p<0,001)$.

Kesimpulan: Formula dengan daya terima tertinggi terdapat pada F4. Satu porsi (33 g) dapat mencukupi $10-15 \%$ dari kebutuhan protein dan besi pada remaja putri berusia $16-21$ tahun.
\end{abstract}

Kata kunci: Protein, Zat Besi, Sosis Hati Ayam Kacang Kedelai, Mutu Hedonik, Daya Terima

\section{ABSTRACT}

Background: Chicken liver is a good source of iron and soybeans are a type of beans of high protein and iron which can be processed into sausages as a snack or side dish high in protein and iron.

Objectives: The purpose of this study was to analyze the results of hedonic, acceptability, protein and iron content with the substitution of chicken liver and soybeans.

Methods: This type of research is pure experimental with completely randomized design (CRD). There are 4 formulas with 4 repetitions, namely F2 (35 g chicken liver and $65 \mathrm{~g}$ soybeans), F3 (45 g chicken liver and $55 \mathrm{~g}$ soybeans), and F4 (55 g chicken liver and $45 \mathrm{~g}$ soybeans). There were 27 panelists in this study who were untrained.

Results: The result of acceptability test showed that the formula F4 (55 g chicken liver and $45 \mathrm{~g}$ soybeans) was the most chosen formula. The protein and iron content per $100 \mathrm{~g}$ of F4 sausage was $17.21 \mathrm{~g}$ and $7.415 \mathrm{mg}$. There was a significant difference between FO and F4 in aroma characteristics ( $p=0.045)$, elasticity $(p<0.001)$ and taste $(p<0.001)$.

Conclusion: The formula with the highest acceptance in F4. One serving (33 g) can meet $10-15 \%$ of protein and iron needs in young women 16-21 years.

Keywords: Protein, Iron, Chicken Liver Sausage Soybeans, Hedonic Quality, Acceptability

*Korrespondensi:

Annisa Nurul Lutfiah

Annisanrl02@gmail.com

${ }^{1}$ Fakultas Kesehatan Masyarakat, Universitas Airlangga, Indonesia 
Lutfiah, dkk. Amerta Nutr (2021). 75-83

DOI: 10.20473 /amnt.v5i1.2021.75-83

\section{PENDAHULUAN}

Salah satu masalah gizi Indonesia yang membutuhkan perhatian khusus yaitu anemia defisiensi besi. Hasil Riskesdas tahun 2007, 2013 dan 2018 menunjukkan prevalensi anemia berdasarkan kelompok umur $15-24$ tahun secara berturut-turut yaitu 6,9 \%, 18,4 $\%$, dan $32 \%$, dimana pada perempuan sebesar $59,9 \%$, 23,9 $\%, 27,2$. Penanganan anemia pada remaja putri adalah dengan pemberian nutrisi yang tepat sesuai kebutuhan ${ }^{1-3}$.

Kebutuhan zat gizi pada remaja putri berbeda dengan remaja laki-laki terutama pada kebutuhan protein dan zat besi. Remaja putri membutuhkan protein dan zat besi lebih tinggi daripada laki-laki dikarenakan pada remaja putri masa pertumbuhan lebih cepat dan menstruasi berkala yang mengeluarkan zat besi setiap bulan ${ }^{4}$. Asupan gizi remaja yang tidak cukup bukan melewatkan waktu makan terutama pada sarapan pagi, akan tetapi karena sering mengkonsumsi junk food ${ }^{5}$.

Sosis adalah salah satu jenis dari fast food yang digemari oleh remaja. Di Indonesia sosis ayam dan sosis sapi yang sering dikonsumsi ${ }^{6}$. Jenis makanan yang sering dikonsumsi pada remaja adalah sosis dan susu masing masing sebesar $42,7 \%$ dan $43,9 \%^{7}$. Cara pembuatan sosis yaitu daging digiling atau dihaluskan, dicampur dengan bumbu dan minyak, diaduk hingga merata, kemudian dicetak dengan selongsong ${ }^{8}$.

Hati ayam adalah salah satu organ yang termasuk limbah atau by-product yang memiliki kandungan zat gizi tinggi dibanding hati yang bersumber dari ternak lainnya. Kandungan gizi pada 100 gram yaitu protein 27,4 g dan zat besi $4 \mathrm{mg}^{9}$. Hati ayam adalah salah satu sumber besi heme yang baik dan mudah diperoleh. Selain itu hati ayam memiliki nilai bioavailabilitas lebih tinggi dibandingkan sumber zat besi lainnya seperti sayuran hijau dan kacangkacangan ${ }^{10}$. Kacang kedelai merupakan salah satu bahan makanan yang diduga dapat mengatasi anemia defisiensi besi. Kandungan protein dan zat besi dalam kacang kedelai menstimulasi produksi sel-sel darah merah sehingga dapat membantu mengobati anemia. Kandungan gizi pada 100 gram kacang kedelai yaitu protein 30,2 g, lemak 15,6 g dan zat besi 6,9 $\mathrm{mg}^{9}$

Penggunaan hati ayam dan kacang kedelai menghasilkan sosis tinggi protein dan zat besi segi mutu maupun jumlah diharapkan dapat menjadi langkah pencegahan dan perbaikan gizi anemia pada remaja putri. Berdasarkan uraian diatas, penelitian ini bertujuan untuk menemukan formula sosis hati ayam dan kacang kedelai yang tepat, menganalisis hasil mutu hedonik, uji daya terima, uji kadar protein dan zat besi pada sosis dengan modifikasi hati ayam dan kacang kedelai sebagai makanan tambahan pada anemia remaja putri.

\section{METODE}

Penelitian ini memakai metode eksperimental murni dimana sampel sosis dikategorikan berdasarkan jenis perlakuan, yaitu formula modifikasi dan kontrol menggunakan metode rancangan acak lengkap (RAL). Ada 7 macam perlakuan dengan 4 kali pengulangan. Penelitian dilakukan dalam dua tahap yaitu penelitian pendahuluan dan penelitian lanjutan yang dilaksanakan bulan Maret sampai bulan April 2020. Proses pembuatan formula sosis dilakukan di Laboratorium Pengolahan Gizi Universitas Airlangga. Uji mutu hedonik pada panelis terbatas yaitu 2 dosen dan 3 alumni Gizi Universitas Airlangga dan uji kesukaan di rumah masing-masing panelis tidak terlatih yaitu mahasiswi Gizi Universitas Airlangga berusia 16-21 tahun, dan uji kadar protein dengan menggunakan metode semi mikro kjeldahl, untuk zat besi dengan destruksi analisa Flame AAS dilakukan di Laboratorium Gizi Universitas Airlangga Surabaya.

\section{Bahan dan Alat Formulasi}

Bahan yang diperlukan pada proses produksi sosis yaitu hati ayam, tepung kacang kedelai, tepung terigu, susu, telur, tepung tapioka, bawang merah, minyak goreng bawang putih, jahe, pala, merica, garam, gula dan es batu. Selongsong atau Casing yang digunakan terbuat dari plastik khusus yang aman untuk produksi formula makanan khususnya sosis. Proporsi bahan yang digunakan dalam produksi sosis berbeda pada masing-masing formula. Substitusi kacang kedelai dan hati ayam bertujuan untuk alternatif sumber protein dan zat besi yang berpengaruh dalam meningkatkan kadar protein dan zat besi pada sosis. Tepung tapioka dan tepung terigu sebagai pemikat air yang mempengaruhi emulsifikasi, sehingga berpengaruh pada tekstur sosis. Formula sosis yang digunakan dalam penelitian ada pada Tabel 1.

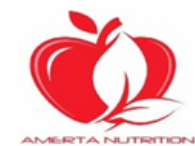

(C)2021. Lutfiah, et al. Open access under CC BY - SA license.

Received: 30-07-2020, Accepted: 27-10-2020, Published online:19-03-2021

doi: 10.20473/amnt.v5i1.2021.75-83. Joinly Published by IAGIKMI \& Universitas Airlangga 
Tabel 1. Formula Sosis

\begin{tabular}{|c|c|c|c|c|c|c|c|}
\hline \multirow{2}{*}{ Bahan } & \multicolumn{7}{|c|}{ Formula (g) } \\
\hline & Fo & F1 & F2 & F3 & F4 & F5 & F6 \\
\hline Daging Ayam & 100 & 0 & 0 & 0 & 0 & 0 & 0 \\
\hline Hati Ayam & - & 25 & 35 & 45 & 55 & 65 & 75 \\
\hline Kacang Kedelai & - & 75 & 65 & 55 & 45 & 35 & 25 \\
\hline Telur & 30 & 30 & 30 & 30 & 30 & 30 & 30 \\
\hline Tapioka & 35 & 35 & 35 & 35 & 35 & 35 & 35 \\
\hline Tepung terigu & 10 & 10 & 10 & 10 & 10 & 10 & 10 \\
\hline Tepung susu skim & 10 & 10 & 10 & 10 & 10 & 10 & 10 \\
\hline Merica Bubuk & 1 & 1 & 1 & 1 & 1 & 1 & 1 \\
\hline Pala bubuk & 1 & 1 & 1 & 1 & 1 & 1 & 1 \\
\hline Jahe & 2 & 2 & 2 & 2 & 2 & 2 & 2 \\
\hline Bawang Putih & 5 & 5 & 5 & 5 & 5 & 5 & 5 \\
\hline Bawang Merah & 2 & 2 & 2 & 2 & 2 & 2 & 2 \\
\hline Garam Dapur & 5 & 5 & 5 & 5 & 5 & 5 & 5 \\
\hline Gula Putih & 2 & 2 & 2 & 2 & 2 & 2 & 2 \\
\hline Es Batu & 20 & 20 & 20 & 20 & 20 & 20 & 20 \\
\hline Minyak Goreng & 30 & 30 & 30 & 30 & 30 & 30 & 30 \\
\hline
\end{tabular}

\section{Proses Pembuatan}

Proses produksi sosis dilakukan melalui 2 tahapan, tahap persiapan dan pengolahan. Tahap persiapan kacang kedelai dijadikan tepung terlebih dahulu. Berikut adalah proses penepungan kacang kedelai: (1) kacang kedelai di rendam selama 8 - 16 jam, (2) kacang kedelai direbus selama 30 menit, (3) kacang kedelai ditiriskan dan dipisahkan kulit ari, (4) kacang kedelai dikeringkan dengan dijemur dibawah sinar matahari atau oven selama 4 jam dengan suhu $50-60^{\circ} \mathrm{C}$, (5) kacang kedelai digiling halus hingga memperoleh tepung kedelai. Selanjutnya hati ayam dihaluskan dengan es batu, bawang merah, bawang putih dan jahe dihaluskan, hati ayam, tepung kacang kedelai, telur, tepung, bumbu halus dan bumbu kering digiling menjadi satu adonan, adonan sosis dicetak sosis dengan menggunakan casing sosis, diikat setiap jarak $15 \mathrm{~cm}$ dan timbang $30 \mathrm{~g}$, kemudian direbus dalam waktu 45 menit dengan suhu maksimum $75^{\circ} \mathrm{C}$. Sosis yang telah masak lalu ditiriskan. Sosis yang sudah dingin siap disantap atau disimpan ke freezer.

\section{Uji Organoleptik}

Sampel dalam penelitian ini yaitu sosis hati ayam substitusi tepung kacang kedelai sesuai komposisi formula yang sudah ditentukan. Sampel yang disajikan kepada panelis yaitu sosis dengan ukuran 10 gram untuk tiap formula. Sampel diambil secara acak dari hasil pengulangan pada setiap perlakuan. Pada uji kesukaan sampel yang dinilai oleh panelis tidak terlatih (27 mahasiswi Gizi Universitas Airlangga berusia $16-21$ tahun) adalah sosis berjumlah 1 formula control dan 4 formula modifikasi yang disajikan dan disediakan angket uji hedonik untuk menilai tingkat kesukaan aroma, warna, rasa dan tekstur (kekenyalan) dengan menggunakan 6 skala tingkat kesukaan ( 1 = sangat tidak suka, 2 = tidak suka, 3 = agak tidak suka, 4 = suka, 5 = agak suka, dan $6=$ sangat suka). Mahasiswi Gizi Universitas Airlangga dipilih sebagai panelis mempertimbangkan sasaran produk yaitu remaja putri berusia 16-21 tahun, sehingga didapatkan penilaian sesuai dengan kesukaan remaja putri dalam pemilihan snack.

\section{Teknik Analisis}

Penilaian uji mutu hedonik dilakukan meliputi warna, tekstur (kekenyalan), aroma dan rasa dari panelis terbatas menggunakan angket uji mutu. Penilaian uji hedonik meliputi aroma, tekstur (kekenyalan), warna dan rasa dari penilaian panelis tidak terlatih menggunakan angket uji hedonik. Menentukan formula terbaik dengan cara memberikan skoring pada nilai zat gizi dan nilai yang sering muncul (modus) untuk uji mutu hedonik dan mean untuk uji hedonik. Skor yang diberikan yaitu skor 1 sampai 6, angka 1 untuk parameter yang tidak sesuai dengan kriteria yang diharapkan, angka 6 untuk parameter yang sesuai dengan kriteria yang diharapkan. Kemudian diberi bobot angka 3 untuk kandungan zat gizi dan angka 4 untuk uji mutu hedonik. Selanjutnya nilai skor dikalikan dengan

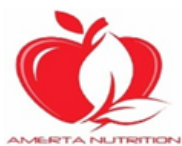

(C)2021. Lutfiah, et al. Open access under CC BY - SA license.

Received: 30-07-2020, Accepted: 27-10-2020, Published online:19-03-2021

doi: 10.20473/amnt.v5i1.2021.75-83. Joinly Published by IAGIKMI \& Universitas Airlangga 
nilai bobot per parameter masing-masing formula kemudian dijumlah dan diranking untuk menentukan formula terbaik. Perhitungan kadar protein zat besi dilakukan melalui uji laboratorium. Uji Shapiro-Wilk digunakan untuk melihat distribusi normal data dan menggunakan uji Kruskal Wallis dengan $\alpha \leq 0,05$ untuk melihat ada tidaknya perbedaan dari semua formula.

\section{HASIL DAN PEMBAHASAN}

Hasil uji mutu hedonik dan ketujuh formula sosis menunjukkan bahwa mayoritas panelis memberikan nilai tertinggi terhadap kualitas warna, tekstur (kekenyalan), rasa dan aroma pada formula kontrol (FO) dan formula modifikasi (F2, F3, dan F4) yang merupakan formula terbaik. Pada penelitian lanjutan diujikan tingkat kesukaan/daya terima sosis pada panelis tidak terlatih yaitu formula kontrol (F0) dan formula modifikasi (F2, F3, F4). Sesuai dengan hasil uji hedonik terhadap tingkat kesukaan tekstur (kekenyalan), aroma, rasa dan warna formula F4 (hati ayam $55 \mathrm{~g}$ dan tepung kacang kedelai $45 \mathrm{~g}$ ) adalah formula terbaik yang lebih disukai oleh panelis. Semakin tinggi substitusi hati ayam dan tepung kacang kedelai maka kekenyalannya semakin baik, daya terima dan kadar protein dan zat besi pada sosis modifikasi semakin meningkat.

\section{Warna}

Warna merupakan salah satu indikator yang digunakan seseorang menilai suatu produk. Hanya dengan melihat suatu warna dapat memperngaruhi presepsi atribut lain seperti rasa, aroma dan flavor ${ }^{11}$. Berdasarkan Tabel 2 hasil dari penilaian panelis, formula F4 mendapatkan penilaian paling tinggi dengan rata-rata
Sedangkan uji Mann Whitney $\alpha \leq 0,05$ untuk melihat perbedaan masing-masing formula yang paling signifikan.

Penelitian ini menggunakan subjek manusia sebagai panelis untuk menilai mutu hedonik dan uji hedonik sosis. Penelitian ini disetujui oleh komisi etik penelitian Fakultas Kedokteran Gigi Universitas Airlangga Surabaya dengan nomor 157-HRECC.FODM.

pemeringkatan (mean rank) sebesar 3,3. Warna yang dihasilkan formula F4 yaitu warna coklat tua. Hati ayam yang memiliki warna merah kecoklatan akan berubah warna menjadi coklat pada sosis setelah melalui proses pengolahan. Sosis yang terbuat dari daging sapi akan memiliki intensitas warna merah yang rendah karena pigmen warna merah daging berasal dari myoglobin yang akan teroksidasi dan terdenaturasi selama pengolahan sehingga sosis yang dihasilkan berwarna coklat ${ }^{12}$.

Hasil analisis pada tabel 6 menunjukkan nilai $p<$ 0,000 yang dapat diartikan bahwa terdapat perbedaan nyata antar warna formula kontrol dengan formula modifikasi (F2, F3, dan F4). Berdasarkan uji lanjut terdapat perbedaan yang signifikan antar formula sosis tepung kacang kedelai dan hati ayam. Hasil analisis uji lanjut menunjukkan terdapat perbedaan warna yang signifikan antara keempat produk sosis tepung kacang kedelai dan hati ayam, yaitu F0 dan F2 ( $p=0,006), F 0$ dan F3 $(p=0,001)$, $F 2$ dan F4 $(p=0,002)$, serta F3 dan F4 $(p<0,000)$. Perbedaan yang signifikan diakibatkan karena perbedaan proporsi formula sosis tepung kacang kedelai dan hati ayam cukup banyak.

Tabel 2. Distribusi Tingkat Kesukaan Panelis Tidak Terlatih terhadap Warna sosis

\begin{tabular}{|c|c|c|c|c|c|c|c|c|c|c|c|c|}
\hline \multirow{2}{*}{$\begin{array}{c}\text { Kode } \\
\text { Sampel }\end{array}$} & \multicolumn{2}{|c|}{1} & \multicolumn{2}{|c|}{2} & \multicolumn{2}{|c|}{3} & \multicolumn{2}{|c|}{4} & \multicolumn{2}{|c|}{ Total } & \multirow{2}{*}{$\begin{array}{l}\text { Skor } \\
\text { Total }\end{array}$} & \multirow{2}{*}{ Mear } \\
\hline & $\mathrm{n}$ & $\%$ & $\mathrm{~N}$ & $\%$ & $n$ & $\%$ & $n$ & $\%$ & $\mathrm{~N}$ & $\%$ & & \\
\hline FO & 1 & 3,7 & 4 & 14,8 & 10 & 37 & 12 & 44,4 & 27 & 100 & 87 & 3,2 \\
\hline F2 & 2 & 7,4 & 6 & 22,2 & 18 & 66,7 & 1 & 3,7 & 27 & 100 & 72 & 2,7 \\
\hline F3 & 4 & 14,8 & 13 & 48,1 & 7 & 25,9 & 3 & 11,1 & 27 & 100 & 63 & 2,3 \\
\hline F4 & 0 & 0 & 4 & 14,8 & 11 & 40,7 & 12 & 44,4 & 27 & 100 & 89 & 3,3 \\
\hline
\end{tabular}

\section{Aroma}

Aroma adalah salah satu parameter dalam menentukan kelezatan dari suatu bahan pangan maupun produk makanan. Aroma yang bagus dapat dilihat dari penampakan atau warna dapat menjadikan produk makanan lebih menarik. Selain menentukan kelezatan aroma juga menjadi salah satu faktor penentu mutu makanan dalam industri pangan ${ }^{13}$. Berdasarkan Tabel 3 hasil dari penilaian panelis, formula FO mendapatkan penilaian paling tinggi dengan rata-rata pemeringkatan (mean rank) sebesar 3,3 dan formula modifikasi tertinggi pada formula F4 dengan rata-rata pemeringkatan (mean rank) sebesar 2,9. Aroma yang dihasilkan formula F4 yaitu beraroma hati ayam. Aroma hati ayam yang khas akan tetap ada pada produk sosis yang telah jadi, selain itu jumlah dan jenis bumbu yang ditambahkan juga akan mempengaruhi aroma sosis ${ }^{14}$.

Hasil analisis pada tabel 6 menunjukkan nilai $\mathrm{p}=$ 0,002 dapat diartikan bahwa terdapat perbedaan nyata antar aroma formula kontrol dengan formula modifikasi (F2, F3, dan F4). Berdasarkan uji lanjut terdapat perbedaan aroma yang signifikan antar formula sosis tepung kacang kedelai dan hati ayam. Hasil analisis uji lanjut menunjukkan terdapat perbedaan aroma yang signifikan antara keempat produk sosis tepung kacang kedelai dan hati ayam, yaitu FO dan F2 ( $p<0,000)$, F0 dan F3 ( $p=0,007)$, serta F0 dan F4 ( $p$ $=0,045)$. Hal ini menunjukkan bahwa aroma khas dari hati ayam sangat mendominansi pada keempat produk sosis

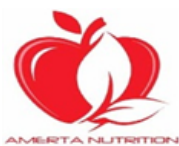

(C)2021. Lutfiah, et al. Open access under CC BY - SA license.

Received: 30-07-2020, Accepted: 27-10-2020, Published online:19-03-2021

doi: 10.20473/amnt.v5i1.2021.75-83. Joinly Published by IAGIKMI \& Universitas Airlangga 
tepung kacang kedelai dan hati ayam serta masih dapat diterima oleh panelis.

Tabel 3. Distribusi Tingkat Kesukaan Panelis Tidak Terlatih terhadap Aroma sosis

\begin{tabular}{|c|c|c|c|c|c|c|c|c|c|c|c|c|}
\hline \multirow{2}{*}{$\begin{array}{c}\text { Kode } \\
\text { Sampel }\end{array}$} & \multicolumn{2}{|c|}{1} & \multicolumn{2}{|c|}{2} & \multicolumn{2}{|c|}{3} & \multicolumn{2}{|c|}{4} & \multicolumn{2}{|c|}{ Total } & \multirow{2}{*}{$\begin{array}{l}\text { Skor } \\
\text { Total }\end{array}$} & \multirow{2}{*}{ Mear } \\
\hline & $n$ & $\%$ & $\mathrm{~N}$ & $\%$ & $n$ & $\%$ & $n$ & $\%$ & $\mathrm{~N}$ & $\%$ & & \\
\hline FO & 0 & 0 & 2 & 7,4 & 16 & 59,3 & 9 & 33,3 & 27 & 100 & 88 & 3,3 \\
\hline F2 & 0 & 0 & 17 & 63 & 6 & 22,2 & 4 & 14,8 & 27 & 100 & 69 & 2,6 \\
\hline F3 & 1 & 3,7 & 8 & 29,6 & 15 & 55,6 & 3 & 11,1 & 27 & 100 & 74 & 2,7 \\
\hline F4 & 0 & 0 & 8 & 29,6 & 14 & 51,9 & 5 & 18,5 & 27 & 100 & 78 & 2,9 \\
\hline
\end{tabular}

\section{Tekstur (Kekenyalan)}

Kekenyalan merupakan salah satu sifat fisik dari sosis. Sosis dapat dikatakan bermutu baik apabila dapat memenuhi standar mutu organoleptik, kimia, dan tekstur sosis harus kenyal, kompak, dan empuk. Daya ikat antar partikel daging dan bahan yang ditambahkan adalah penentu kualitas sosis ${ }^{15}$.

Berdasarkan Tabel 4 hasil dari penilaian panelis, formula FO mendapatkan penilaian paling tinggi dengan rata-rata pemeringkatan (mean rank) sebesar 3,5 yang menjadi formula kontrol dan formula modifikasi tertinggi pada formula $\mathrm{F} 4$ dengan rata-rata pemeringkatan (mean rank) sebesar 2,7. Kekenyalan yang dihasilkan formula F4 dan F0 yaitu lunak dan empuk. Hasil analisis menunjukkan adanya perbedaan nyata antar kekenyalan formula kontrol dengan formula modifikasi (F2, F3, dan F4) dengan nilai $p<$ 0,000 . Berdasarkan uji lanjut terdapat perbedaan kekenyalan yang signifikan antar formula sosis tepung kacang kedelai dan hati ayam

Hasil analisis uji lanjut pada tabel 6 menunjukkan terdapat perbedaan tekstur yang signifikan antara keempat produk sosis tepung kacang kedelai dan hati ayam, yaitu FO dan F2 $(p<0,000)$, F0 dan F3 (p<0,000), F0 dan F4 ( $p<$ $0,000)$, F2 dan F4 ( $<<0,000)$ serta F3 dan F4 $(p<0,000)$. Hal ini membuktikan bahwa semakin sedikit proporsi tepung kacang kedelai yang ditambahkan semakin kenyal tekstur sosis. Hal ini disebabkan tepung kacang kedelai memiliki kadar air lebih sedikit dan dapat mengikat air lebih banyak sehingga dapat mempengaruhi kekenyalan sosis. Tepung kedelai adalah salah satu bahan pemikat yang dapat menambah daya ikat air pada bahan makanan dikarenakan adanya pati dan protein yang dapat mengikat air ${ }^{16}$.

Tekstur sosis yang kenyal dan padat juga dipengaruhi oleh peranan amilopektin dan amilosa pada tepung tapioka. Amilopektin merupakan fraksi terlarut dan amilosa adalah fraksi tidak terlarut ${ }^{17}$. Sosis dipengaruhi oleh penggunaan putih telur dan tapioka. Sebagian air yang ditambahkan pada adonan dapat diikat dengan molekulmolekul protein putih telur yang mengalami koagulasi sehingga tekstur sosis menjadi lebih padat. Tepung tapioka yang digunakan mempunyai kemampuan gelatinisasi dan pembentukan gel sehingga dapat memperbaiki tekstur sosis $^{18}$.

Tabel 4. Distribusi Tingkat Kesukaan Panelis Tidak Terlatih terhadap Tekstur sosis

\begin{tabular}{|c|c|c|c|c|c|c|c|c|c|c|c|c|}
\hline \multirow{2}{*}{$\begin{array}{c}\text { Kode } \\
\text { Sampel }\end{array}$} & \multicolumn{2}{|c|}{1} & \multicolumn{2}{|c|}{2} & \multicolumn{2}{|c|}{3} & \multicolumn{2}{|c|}{4} & \multicolumn{2}{|c|}{ Total } & \multirow{2}{*}{$\begin{array}{l}\text { Skor } \\
\text { Total }\end{array}$} & \multirow{2}{*}{ Mear } \\
\hline & $\mathrm{n}$ & $\%$ & $\mathrm{~N}$ & $\%$ & $\mathrm{n}$ & $\%$ & $\mathrm{n}$ & $\%$ & $\mathrm{~N}$ & $\%$ & & \\
\hline F0 & 0 & 0 & 3 & 11,1 & 8 & 29,6 & 16 & 59,3 & 27 & 100 & 95 & 3,5 \\
\hline F2 & 5 & 18,5 & 18 & 66,3 & 3 & 11,1 & 1 & 3,7 & 27 & 100 & 52 & 1,9 \\
\hline F3 & 7 & 25,9 & 16 & 59,3 & 4 & 14,8 & 0 & 0 & 27 & 100 & 50 & 1,9 \\
\hline F4 & 1 & 3,7 & 8 & 29,6 & 16 & 59,3 & 2 & 7,4 & 27 & 100 & 72 & 2,7 \\
\hline
\end{tabular}

\section{Rasa}

Rasa merupakan indikator penting dalam penilaian produk makanan dengan menggunakan panca indera pengecap yaitu rasa asin, manis dan pahit ${ }^{19}$. Rasa suatu produk pangan berasal dari bahan pangan itu sendiri. Selain bahan utama, bumbu yang digunakan dalam proses pengolahan dapat meningkatkan daya terima produk dan menambah cita rasa produk ${ }^{20}$. Berdasarkan Tabel 5 hasil penilaian panelis, formula FO mendapatkan penilaian paling tinggi dengan rata-rata pemeringkatan (mean rank) sebesar 3,6 yang menjadi formula kontrol dan formula modifikasi tertinggi pada formula F3 dan F4 dengan rata-rata pemeringkatan (mean rank) sebesar 2,4. Rasa yang

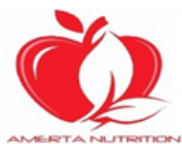

(C)2021. Lutfiah, et al. Open access under CC BY - SA license.

Received: 30-07-2020, Accepted: 27-10-2020, Published online:19-03-2021

doi: 10.20473/amnt.v5i1.2021.75-83. Joinly Published by IAGIKMI \& Universitas Airlangga 
dihasilkan formula F0 yaitu rasa daging ayam dikarenakan formula kontrol yang digunakan adalah sosis ayam. Pemberian tepung kacang kedelai lebih banyak akan menambah rasa gurih pada sosis. Formulasi ini sejalan dengan penelitian Ara (2018), formula biscuit dengan penambahan kedelai memiliki rasa gurih yang dihasilkan oleh lemak dan protein dalam biscuit ${ }^{21}$. Kandungan protein tepung kedelai dapat menambah rasa gurih ${ }^{22}$.

Tabel 5. Distribusi Tingkat Kesukaan Panelis Tidak Terlatih terhadap Tekstur sosis

\begin{tabular}{|c|c|c|c|c|c|c|c|c|c|c|c|c|}
\hline \multirow{2}{*}{$\begin{array}{c}\text { Kode } \\
\text { Sampel }\end{array}$} & \multicolumn{2}{|c|}{1} & \multicolumn{2}{|c|}{2} & \multicolumn{2}{|c|}{3} & \multicolumn{2}{|c|}{4} & \multicolumn{2}{|c|}{ Total } & \multirow{2}{*}{$\begin{array}{l}\text { Skor } \\
\text { Total }\end{array}$} & \multirow{2}{*}{ Mear } \\
\hline & $n$ & $\%$ & $\mathrm{~N}$ & $\%$ & $\mathrm{n}$ & $\%$ & $n$ & $\%$ & $\mathrm{~N}$ & $\%$ & & \\
\hline F0 & 0 & 0 & 2 & 7,4 & 8 & 29,6 & 17 & 62,9 & 27 & 100 & 96 & 3,6 \\
\hline F2 & 5 & 18,5 & 15 & 55,6 & 5 & 18,5 & 2 & 7,4 & 27 & 100 & 58 & 2,1 \\
\hline F3 & 3 & 11,1 & 12 & 44,4 & 10 & 37 & 2 & 7,4 & 27 & 100 & 66 & 2,4 \\
\hline F4 & 1 & 3,7 & 15 & 55,6 & 8 & 29,6 & 3 & 11,1 & 27 & 100 & 66 & 2,4 \\
\hline
\end{tabular}

Hasil analisis pada tabel 6 menunjukkan terdapat perbedaan nyata antar rasa formula kontrol dengan formula modifikasi (F2, F3, dan F4) dengan nilai $p<0,000$. Berdasarkan uji lanjut terdapat perbedaan rasa yang signifikan antar formula sosis tepung kacang kedelai dan hati ayam. Hasil analisis uji lanjut menunjukkan terdapat perbedaan aroma yang signifikan antara keempat produk sosis tepung kacang kedelai dan hati ayam, yaitu F0 dan F2 $(p<0,000)$, F0 dan F3 ( $p<0,000)$, serta F0 dan F4 ( $p<0,000)$. Hal ini menunjukkan bahwa semakin banyak proporsi tepung kacang kedelai yang ditambahkan semakin gurih rasa sosis. Hal ini membuktikan bahwa tepung kacang kedelai mengandung protein yang dapat menambah rasa gurih pada sosis.

Tabel 6. Distribusi Tingkat Kesukaan terhadap Mutu Hedonik Sosis

\begin{tabular}{|c|c|c|c|c|c|}
\hline \multirow{2}{*}{ Indikator } & \multicolumn{4}{|c|}{ Formula } & \multirow{2}{*}{$p$-value } \\
\hline & FO & $\mathrm{F} 2$ & F3 & F4 & \\
\hline Warna & $66,56^{a}$ & $46,80^{b}$ & $36,11^{a c}$ & $68,54^{b c}$ & 0,000 \\
\hline Aroma & $70,48^{a b}$ & 41,43 & $50,57^{a}$ & $55,52^{b}$ & 0,002 \\
\hline Kekenyalan & $87,13^{a b c}$ & $35,37^{\text {ade }}$ & $33,19^{b}$ & $62,31^{c d e}$ & 0,000 \\
\hline Rasa & $83,54^{a b c}$ & $38,35^{a}$ & $48,65^{b}$ & $47,46^{c}$ & 0,000 \\
\hline
\end{tabular}

Keterangan: Angka yang diikuti dengan huruf yang berbeda pada baris yang sama menunjukkan adanya perbedaan nyata $(p<0,05$

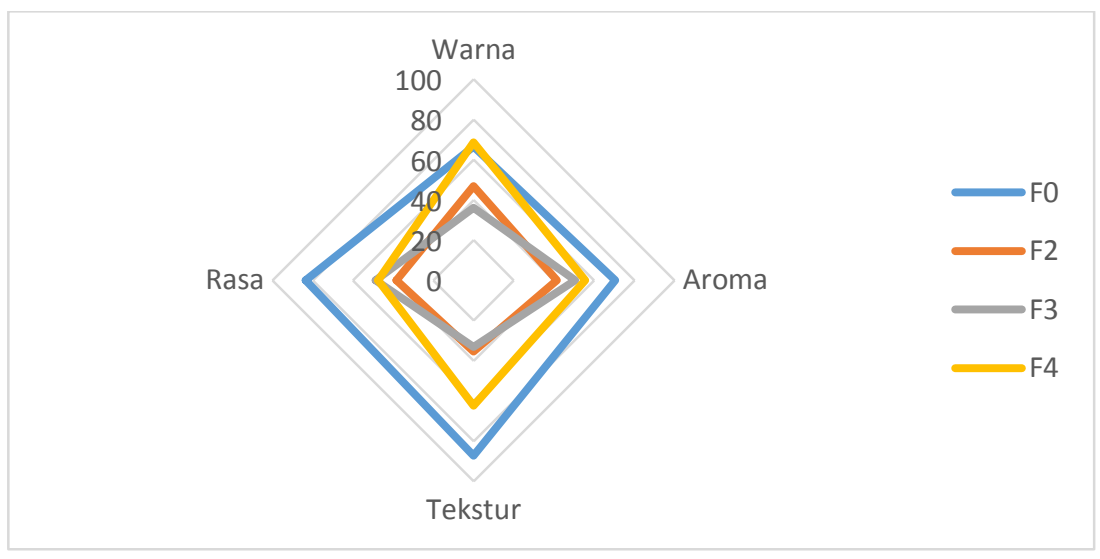

Gambar 1. Tingkat Kesukaan Panelis secara Umum terhadap Sosis

\section{Tingkat Kesukaan Karakteristik secara Umum}

Pada penilaian tingkat kesukaan panelis secara umum merupakan penilaian secara menyeluruh terhadap mutu organoleptik sosis yaitu warna, aroma, tekstur, dan rasa. Rata-rata penilaian tertinggi adalah formula FO yang merupakan formula tanpa substitusi tepung kacang kedelai dan hati ayam berdasarkan gambar 1 , sedangkan formula modifikasi paling disukai adalah F4 yang merupakan sosis dengan substitusi tepung kacang kedelai dan hati ayam, dengan bahan substitusi kacang kedelai lebih sedikit dan

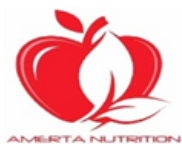

(C)2021. Lutfiah, et al. Open access under CC BY - SA license.

Received: 30-07-2020, Accepted: 27-10-2020, Published online:19-03-2021

doi: 10.20473/amnt.v5i1.2021.75-83. Joinly Published by IAGIKMI \& Universitas Airlangga 
hati ayam lebih banyak diantara formula lain yang diujikan pada penelitian lanjutan. Formula F4 merupakan formula modifikasi yang unggul pada penilaian warna, aroma, tekstur (kekenyalan) dan rasa. Penilaian panelis terhadap daya terima sosis berdasarkan tingkat kesukaan yang menunjukkan bahwa formula modifikasi sosis dapat diterima dan dijadikan alternatif makanan tinggi protein dan zat besi. Penilaian terbaik berdasarkan daya terima yaitu formula F4.

\section{Protein}

Kandungan protein pada formula F4 relatif lebih tinggi dibandingan dengan protein formula lain yaitu $24,6 \mathrm{~g}$ per $100 \mathrm{~g}$ sosis, perhitungan tersebut berdasarkan tabel komposisi pangan indonesia ${ }^{9}$. Sosis yang terbuat dari tepung kacang kedelai dengan hati ayam dapat memberikan protein sebanyak $17,21 \%$. Persentase dari hasil uji laboratorium setara dengan satuan gram berdasarkan pada pengujian tiap $100 \mathrm{~g}$. Jumlah tersebut sesuai dengan hasil laboratorium zat gizi. Sosis tepung kacang kedelai dengan hati ayam dapat mencukupi $10-15 \%$ kebutuhan protein. Selain itu, sosis telah memenuhi syarat mutu sosis daging kombinasi SNI 3820: 2015 yaitu jumlah protein minimal $8 \% \mathrm{~b} / \mathrm{b}$. Hal ini membuktikan bahwa sosis yang dibuat layak untuk dikonsumsi sebagai makanan tinggi protein. Setiap sajian sosis dengan berat $33 \mathrm{~g}$, maka mengkonsumsi 1 sosis sudah dapat memenuhi kebutuhan gizi harian sebesar $10-15 \%$.

Hasil uji laboratorium terdapat penurunan kadar protein perhitungan tabel komposisi pangan yaitu Tabel Komposisi Pangan Indonesia sebesar 30 \%. Sosis melalui tiga proses pemanasan, yaitu perebusan kacang kedelai selama 30 menit, pengeringan kacang kedelai dengan suhu $60^{\circ} \mathrm{C}$ selama 3 jam dan perebusan sosis selama 45 menit. Pada proses pemanasan menyebabkan proses denaturasi protein, yaitu perubahan struktur molekul protein tanpa terjadi pemecahan ikatan-ikatan kovalen ${ }^{19}$.

\section{Zat Besi}

Kandungan zat besi pada formula F4 relatif lebih tinggi dibandingan dengan formula lain yaitu $8,9 \mathrm{mg}$ per 100 g sosis, perhitungan tersebut berdasarkan Tabel Komposisi Pangan Indonesia ${ }^{9}$. Sosis yang terbuat dari tepung kacang kedelai dengan hati ayam dapat memberikan zat besi sebanyak $7,4 \%$. Persentase dari hasil uji laboratorium setara dengan satuan $\mathrm{mg}$ berdasarkan pada pengujian tiap $100 \mathrm{~g}$. Jumlah tersebut sesuai dengan hasil laboratorium zat gizi. Sosis tepung kacang kedelai dengan hati ayam dapat mencukupi $10-15 \%$ kebutuhan zat besi.

Hasil uji laboratorium terdapat penurunan kadar zat besi perhitungan tabel komposisi pangan indonesia 2019 sebesar $16,7 \%^{9}$. Sosis melalui tiga proses pemanasan, yaitu perebusan kacang kedelai selama 30 menit, pengeringan kacang kedelai dengan suhu $60^{\circ} \mathrm{C}$ selama 3 jam dan perebusan sosis selama 45 menit. Proses pengolahan dengan perebusan dapat menurunkan kandungan gizi pada makanan terutama penurunan mineral yaitu zat besi sekitar $5-40 \%{ }^{23}$

\section{Kecukupan Nilai Gizi}

Kecukupan nilai gizi sosis dihitung untuk mengetahui kontribusi pemenuhan zat gizi sosis terhadap AKG remaja usia 16-21 tahun. Berikut ini adalah kecukupan nilai gizi sosis dapat disajikan pada tabel 3. Berdasarkan tabel 5 diketahui bahwa nilai gizi sosis dari hasil uji laboratorium setiap takaran saji sosis dapat berkontribusi sebesar 8,8-9,6\% terhadap kecukupan protein dan 13,7$16,5 \%$ terhadap kecukupan zat besi. Kecukupan gizi snack (sosis) remaja sebesar 10-15\% apabila mengkonsumsi sebanyak 1 buah sosis

Peran protein untuk mengatasi anemia defisiensi besi yaitu berperan dalam proses transportasi zat besi didalam tubuh. Apabila asupan protein kurang maka akan mengakibatkan transportasi zat besi terhambat sehingga terjadi defisiensi zat besi. Tingkat konsumsi protein memiliki hubungan paling kuat terhadap kadar hemoglobin. Selain itu makanan yang tinggi protein terutama berasal dari hewani banyak mengandung zat besi ${ }^{24}$. Sosis modifikasi yang dihasilkan memiliki kandungan protein lebih tinggi dibandingkan formula kontrol. Hal ini sejalan dengan penelitian yang dilakukan oleh Wulandari, et al (2013) yang menyatakan bahwa nilai zat gizi protein pada sosis tempe yang telah dibuat lebih unggul dibandingkan dengan sosis ayam maupun sosis sapi yang telah beredar di pasaran. Penggunaan tempe kedelai, ISP dan putih telur merupakan sumber protein pada pembuatan sosis. Dengan adanya produk sosis yang tinggi protein ini dapat mencukupi kebutuhan zat gizi remaja khususnya protein serta dapat mencegah kejadian anemia defisiensi zat besi pada remaja putri ${ }^{18}$.

Peran zat besi untuk mengatasi anemia defisiensi besi yaitu membantu dalam proses pembentukan atau peningkatan sel darah merah ${ }^{25}$. Apabila asupan zat besi tidak memadai maka akan mempengaruhi peningkatan arbsorbsi besi dari makanan, memobilisasi simpanan zat besi dalam tubuh dan mengurangi transportasi besi ke sumsum tulang, serta menurunkan kadar hemoglobin sehingga mengakibatkan anemia defisiensi zat besi ${ }^{26}$.

Penyebab utama anemia defisiensi zat besi pada remaja pada umumnya adalah asupan zat besi tidak sesuai dengan yang dibutuhkan. Asupan besi yang kurang akibat dari jumlah besi yang di konsumsi dan pengaruh bioavailabilitas zat besi. Bioavailabilitas dipengaruhi oleh faktor pendorong (enchancer) dan faktor penghambat (inhibitor) yang terdapat dalam bahan makanan. Faktor pendorong (enchancer) adalah vitamin A, Vitamin C, Vitamin B2 dan Vitamin B6 untuk meningkatkan penyerapan zat besi ${ }^{27}$. Faktor penghambat (inhibitor) adalah tannin, kalsium, fosfat dan fitat akan mengganggu penyerapan zat besi ${ }^{28}$. Konsumsi sosis modifikasi hati ayam

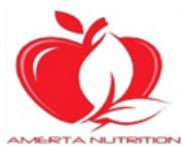

(C)2021. Lutfiah, et al. Open access under CC BY - SA license.

Received: 30-07-2020, Accepted: 27-10-2020, Published online:19-03-2021

doi: 10.20473/amnt.v5i1.2021.75-83. Joinly Published by IAGIKMI \& Universitas Airlangga 
dan kacang kedelai ini dapat dikombinasikan dengan makanan yang mengandung vitamin A, C, B2 dan B6 misalnya ikan, telur, pisang, tomat, manga, jambu, papaya dan jeruk untuk meningkatkan penyerapan zat besi. Hindari makanan seperti tempe, tahu, teh, kopi, susu dan keju agar penyerapan zat besi tidak terhambat.

Tabel 7. Distribusi Nilai Protein dan Zat Besi Berdasarkan Perhitungan TKPI dan Hasil Laboratorium serta Kecukupan Nilai Gizi Sosis

\begin{tabular}{lcccccccc}
\hline Zat Gizi & $\begin{array}{c}\text { Umur } \\
\text { (tahun) }\end{array}$ & AKG & $\begin{array}{c}\text { Pemenuhan } \\
\text { Protein (\%) }\end{array}$ & $\begin{array}{c}\text { Kebutuhan } \\
\text { gizi snack }\end{array}$ & $\begin{array}{c}\text { Perhitungan } \\
\text { TKPI }\end{array}$ & $\begin{array}{c}\text { Hasil } \\
\text { Laboratorium }\end{array}$ & $\begin{array}{c}\text { Zat gizi per } \\
\text { takaran saji }\end{array}$ & $\begin{array}{c}\text { Kontribusi } \\
\text { AKG (\%) }\end{array}$ \\
\hline Protein & $16-18$ & 65 & & $6,5-9,75$ & 24,6 & \multirow{2}{*}{17,21} & 5,73 & 8,8 \\
(g) & $19-21$ & 60 & \multirow{2}{*}{$10-15$} & $\begin{array}{c}6-9 \\
1,5-2,25\end{array}$ & & & 5,73 & 9,6 \\
Zat Besi & $16-18$ & 15 & & \multirow{2}{*}{8,9} & 7,415 & 2,47 & 16,47 \\
(mg) & $19-21$ & 18 & & $1,8-2,7$ & & & 2,47 & 13,72 \\
\hline
\end{tabular}

\section{KESIMPULAN}

Sosis dengan modifikasi hati ayam dan kacang kedelai dengan tingkat mutu hedonik terbaik secara berturut-turut yaitu formula F2, F3, dan F4 dan daya terima tertinggi pada formula $F 4$, penentuan formula terbaik ini dengan cara pembobotan mutu hedonik serta kandungan zat gizi protein dan zat besi formula. Pengujian kandungan nilai gizi di laboratorium untuk formula terbaik yaitu formula 4 yaitu $17,21 \mathrm{~g}$ potein dan $7,415 \mathrm{mg}$ zat besi (100 g). Nilai protein dan zat besi pada formula terbaik (F4) telah sesuai dengan standar mutu sosis modifikasi SNI No. 3820: 2015 (minimal $8 \mathrm{~g}$ per $100 \mathrm{~g}$ sosis) dan satu porsi (33 g) dapat mencukupi $10-15 \%$ dari kebutuhan protein dan zat besi pada remaja putri berusia $16-21$ tahun.

\section{ACKNOWLEDGMENT}

Penulis berterimakasih sebesar-sebesarnya kepada bapak Annis Catur Adi selaku pembimbing utama dan bapak Dominikus Raditya Atmaka departemen Gizi Fakultas Kesehatan Masyarakat Universitas Airlangga Surabaya.

\section{REFERENSI}

1. Kemenkes, R. Riset Kesehatan Dasar Laporan Nasional 2007. (2007).

2. Kemenkes, R. Riset Kesehatan Dasar Tahun 2010. (2010).

3. Kemenkes, R. Riset Kesehatan Dasar 2013. (2013).

4. Adriani, M. \& Wirjatmadi, B. Pengantar Gizi Masyarakat. Pengantar Gizi Masyarakat (Kencana Prenada Media Group, 2012).

5. Arisman. Buku Ajar IImu Gizi GIZI DALAM DAUR KEHIDUPAN . (EGC, 2010).

6. Alamsyah, Y. Membuat Sendiri Frozen Food: Sosis Tanpa Bahan Pengawet. (PT Gramedia Pustaka Utama, 2005).

7. Agnestiya, H. Gambaran Pemilihan dan Frekuensi Konsumsi Makanan Jajanan Pada Remaja Di SMP Negeri 4 Lubuk Pakam. Politeknik Kesehatan Medan vol. 3 (Politeknik Kesehatan Medan, 2019).

8. Anjarsari, B. Pangan Hewani Fisiologi Pasca Mortem dan Teknologi.pdf. (2010).

9. Kemenkes, R. Tabel Komposisi Pangan Indonesia
(TKPI)

2019. http://www.andrafarm.com/_andra.php?_i=dafta r-tkpi (2019).

10. Zarianis. Efek Suplementasi Besi-Vitamin C Dan Vitamin C Terhadap Kadar Hemoglobin Anak Sekolah Dasar Yang Anemia Di Kecamatan Sayung Kabupaten Demak. J. Kesehat. Masy. (2006) doi:10.1007/s00330-009-1556-6.

11. Adawiyah, D. R. Foodreview Indonesia : Pengukuran Warna Produk Pangan. VIII, 52-58 (2013).

12. Atma, Y. Studi Penggunaan Angkak Sebagai Pewarna Alami dalam Pengolahan Sosis Daging Sapi. Teknologi 7, 76-85 (2015).

13. Asmaraningtyas, D. Kekerasan, Warna dan Daya Terima Biskuit yang Disubstitusi Tepung Labu Kuning. Progr. Stud. Ilmu Gizi Jenjang S1. Fak. IImu Kesehatan. Univ. Muhammadiyah Surakarta 17 (2014).

14. Daningtyas, E. Sifat Fisik dan Daya Terima. (Institut Pertanian Bogor, 2001).

15. Koapaha, T., Langi, T. \& Lalujan, L. E. PENGGUNAAN PATI SAGU MODIFIKASI FOSFAT TERHADAP SIFAT ORGANOLEPTIK SOSIS IKAN PATIN (Pangasius hypophtalmus). Lampung University

https://www.coursehero.com/file/17715969/103 -122-2-PB-2/ (2011).

16. Virgo, S. D. H. Pengaruh Pemberian Tepung Kedelai Terhadap Daya Simpan Nugget Ayam Ras Afkir. (Andalas, 2007).

17. Simanjutak, T. Komponen Gizi dan Terapi Pangan ala Papua. (Deepublish, 2014).

18. Wulandari, D., Komar, N. \& Sumarlan, S. H. Perekayasaan pangan berbasis produk lokal Indonesia (studi kasus sosis berbahan baku tempe kedelai). J. Bioproses Komod. Trop. 1, 73-82 (2013).

19. Winarno, F. . Kimia Pangan dan Gizi. (Granedia Pustaka Utama, 1997).

20. Prayitno, A. H. et al. Karakteristik sosis dengan fortifikasi $\beta$-caroten dari labu kuning (Cucurbita moschata) . Bul. Peternak. 33, 111-118 (2009). 
21. Ara, N. R. T. Uji Daya Terima Biskuit Ubi Jalar dan Tepung Kedelai sebagai Makanan Alternatif untuk Anak Autis serta Kandungan Gizinya. 1-72 (2018).

22. Alamsyah, Y. Aneka Resep dan Kiat Usaha Pisang Crispy dan Kentang Bumbu. (Gramedia Pustaka Utama, 2011).

23. Khomsan, A. Susut Gizi Akibat Proses Pemasakan. https://www.kompas.com/kesehatan/news/0204 /23/015943.htm (2002).

24. Maesaroh. TINGKAT KONSUMSI ENERGI, PROTEIN DAN ZAT BESI, HUBUNGANNYA DENGAN KADAR HB. (Sam Ratulangi, 2007).

25. Soehardi, S. Memelihara Kesehatan Jasmani Melalui Makanan. (Institut Teknologi Bandung, 2004).

26. Gibney, M. J., Margaretts, B. M., Kearney, J. M. \& Arab, L. Gizi Kesehatan Masyarakat. (EGC, 2013).

27. Marya, R. K. Buku Ajar Patofisiologi Mekanisme Terjadinya Penyakit. (Binarupa Aksara, 2013).

28. Sizer, F. S. \& Whitney, E. Nutrition: Concepts and Controversies. (Brooks Cole, 2013). 